\title{
Dashboard Executive Information System dengan Pendekatan Sistem Terdistribusi untuk Pemantauan Penyaluran Kredit KUR Mikro Bank X
}

\author{
Putu Oka Yudiantara, I Made Sukarsa, Ni Putu Sutramiani \\ Program Studi Teknologi Informasi, Fakultas Teknik, Universitas Udayana \\ e-mail: putuokayudiantara@gmail.com, sukarsa@unud.ac.id, sutramiani@unud.ac.id
}

\begin{abstract}
Abstrak
KUR Mikro (Kredit Usaha Rakyat) adalah variasi produk kredit yang disalurkan oleh kantor-kantor unit bank dengan target penyaluran berbeda-beda untuk setiap unitnya. Pencapaian target penyaluran di kantor unit dipantau oleh kantor cabang, sehingga diperlukan sistem yang dapat menangani hal tersebut. Dashboard Executive Information System dengan pendekatan terdistribusi dapat digunakan untuk memantau target pencapaian penyaluran KUR Mikro di setiap kantor unit Bank X. Web service digunakan untuk menjembatani komunikasi pada sistem terdistribusi. Dashboard Executive Information System digunakan oleh kepala cabang untuk memantau grafik data nasabah KUR Mikro. Kepala cabang dapat memantau perbandingan pencapaian target jumlah nasabah antar kantor unit pada sistem. Dashboard Executive Information System dapat berinteraksi dengan tiga entitas yaitu admin, kantor cabang dan kantor unit. Web Dashboard Executive Information System terdiri dari 17 halaman yang digunakan untuk manajemen data. Hasil pengujian dan analisa menunjukkan seluruh halaman web serta sinkronisasi berupa data nasabah, data pemohon, data pencairan dan data pembayaran kredit usaha rakyat dapat digunakan dengan status uji sukses.
\end{abstract}

Kata Kunci: web service, Dashboard Executive Information System, KUR

\begin{abstract}
KUR Mikro (Micro Business Loan) is a variation of credit products distributed by bank unit offices with different distribution targets for each unit. The achievement of the distribution target in the unit office is monitored by the branch office, so a system that can handle it is needed. The Executive Information System Dashboard with a distributed approach can be used to monitor the achievement targets for Micro KUR distribution in each office of the Bank $X$ unit. Web services are used to bridge communication on distributed systems. The Executive Information System dashboard is used by the head of the branch to monitor the customer data graph of KUR Mikro. The branch head can monitor the comparison of the achievement of the target number of customers between unit offices in the system. The Executive Information System Dashboard can interact with three entities, namely admin, branch office and unit office. The Executive Information System Web Dashboard consists of 17 pages that are used for data management. Test and analysis results show all web pages and synchronization in the form of customer data, applicant data, disbursement data, and people's business credit payment data can be used with successful test status.
\end{abstract}

Keywords: web service, Dashboard Executive Information System, KUR

\section{Pendahuluan}

Perkembangan industri perbankan memunculkan variasi kredit berupa KUR (Kredit Usaha Rakyat) Mikro [1]. KUR Mikro merupakan kredit atau pembiayaan kepada Usaha Mikro Kecil Menengah Koperasi (UMKM-K) dalam bentuk pemberian modal kerja dan investasi. Pembiayaan melalui KUR Mikro didukung dengan fasilitas penjaminan untuk usaha produktif.

KUR Mikro disalurkan kepada masyarakat melalui kantor unit bank. Setiap kantor unit umumnya memiliki target penyaluran KUR Mikro. Pencapaian target kantor unit dipantau oleh kantor cabang dalam satu wilayah kerja. Masing-masing kantor unit memiliki target yang berbeda, sehingga proses pemantauan tidak efektif apabila dilakukan secara manual.

Kantor cabang memerlukan aplikasi terintegrasi yang memudahkan dalam memantau target penyaluran KUR Mikro di setiap kantor unit. Dashboard Executive Information System yang 
dikembangkan pada penelitian ini dapat menjadi solusi untuk melakukan pemantauan target penyaluran KUR Mikro di setiap kantor unit. Dashboard Executive Information System menerapkan pendekatan terdistribusi yang sesuai dengan kondisi antara kantor unit dan kantor cabang. Proses komunikasi dalam sistem terdistribusi ditangani melalui web service.

Sistem terdistribusi dan pertukaran data menggunakan web service telah beberapa kali diteliti sebelumnya. Dhore dan kawan-kawan di tahun 2012 melakukan penelitian dengan judul "Systematic Approach for Composing Web service using XML". Web service memiliki parameter QOS (Quality of Service) tersendiri, sehingga penyesuaiannya dilakukan dengan algoritma service composition [2]. Park dan kawan-kawan pada tahun 2014 meneliti HTML5 WebSocket untuk komunikasi multimedia. WebSocket mampu meningkatkan kinerja dan mengurangi beban jaringan sehingga sering digunakan untuk komunikasi data dua arah secara real-time [3]. Decheng Qiu dan kawan-kawan pada 2016 melakukan penelitian mengenai integrasi data dengan web service dan XML. Menurut Qiu dan kawan-kawan pertukaran data terdistribusi menggunakan web service dan XML dapat diwujudkan melalui layanan sistem meminta dan memanggil. Data yang disediakan oleh sistem aplikasi tidak perlu disalin ke platform database pusat, tapi diterbitkan dalam bentuk web service [4].

Beberapa penerapan web service yang telah dipaparkan, mendasari pengembangan Dashboard Executive Information System menggunakan pendekatan sistem terdistribusi yang memanfaatkan web service untuk memantau perkembangan nasabah KUR. Dashboard Executive Information System diharapkan memudahkan kantor unit untuk memanajemen data nasabah serta memudahkan kantor cabang dalam memantau target penyaluran KUR dengan data perkembangan nasabah yang disajikan dalam bentuk grafik.

\section{Metodologi Penelitian}

Dashboard Executive Information System dikembangkan dengan metode Waterfall. Metodologi Waterfall membuat pengerjaan sistem dilakukan secara berurutan atau linear. Langkah selanjutnya tidak dapat dikerjakan apabila langkah sebelumnya belum diselesaikan. Gambar 1 menunjukkan urutan langkah pengerjaan sistem dengan metode Waterfall.

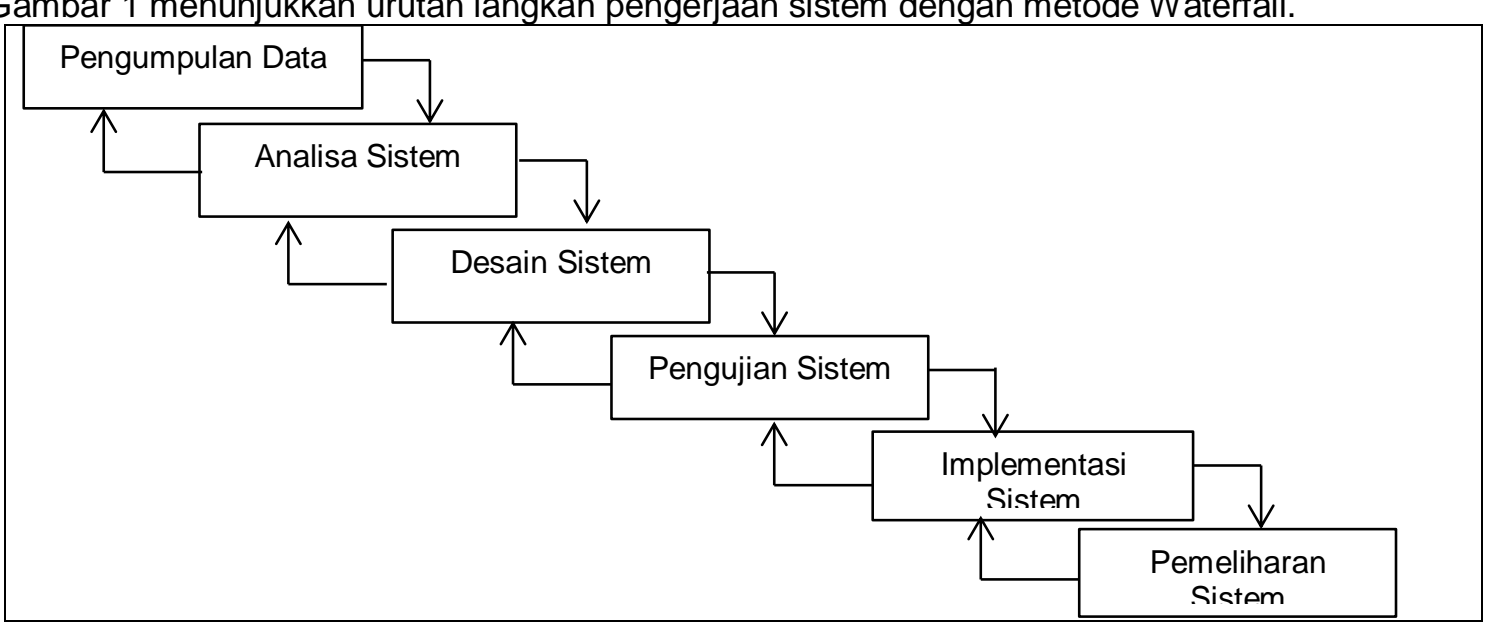

Gambar 1. Langkah-Langkah Pengembangan Sistem dengan Metode Waterfall

Pengembangan sistem dimulai dengan proses pengumpulan data, kemudian dilanjutkan dengan analisa sistem dan kebutuhannya. Fase selanjutnya adalah melakukan desain sistem berupa desain bisnis proses maupun desain antarmuka. Desain yang dihasilkan diuji pada tahapan pengujian sistem. Implementasi sistem dilakukan apabila proses pengujian telah selesai. Rancangan yang telah diimplementasikan secara keseluruhan masuk ke tahap selanjutnya yaitu pemeliharaan sistem.

\section{Kajian Pustaka}

Kajian Pustaka memuat teori-teori penunjang yang melandasi penelitian ini. Teori-teori yang menjadi dasar penelitian yaitu mengenai web service, XML dan PHP. Masing-masing dasar teori dimuat pada bagian 3.1 sampai dengan bagian 3.3. 


\subsection{Web service}

Web service adalah konsep pengembangan aplikasi yang muncul untuk mendukung sistem terdistribusi. Pengaplikasian web service dapat dilakukan menggunakan XML dengan standar protokol SOAP dan HTTP. Keberadaan teknologi XML membuat web service mendukung integrasi berbagai platform dan aplikasi, baik berupa infrastruktur, intranet hingga ekstranet [5].

Arsitektur web service pada umumnya terdiri dari tiga komponen utama yaitu service provider, service requestor dan service registry. Service provider adalah layanan yang menyediakan kumpulan web services yang dapat diakses oleh pengguna. Permintaan layanan (web service) dapat dilakukan oleh pengguna melalui service requestor. Service registry merupakan tempat bagi service provider untuk mempublikasikan layanannya, dimana komponen ini bersifat opsional [6].

\section{2. $X M L$}

XML (Ekstensible Markup Language) adalah sebuah tool untuk transmisi informasi yang bersifat cross-platform. Sesuai dengan namanya, XML adalah dokumen markup sama seperti HTML. Perbedaan XML dengan HTML yaitu fokusnya terhadap data, dimana XML cenderung digunakan untuk transmisi, sedangkan HTML untuk menampilkan data [7]. Protokol jaringan dengan XML yaitu XMLHttpRequests dapat meningkatkan performa sistem ketika digunakan di level perusahaan atau remote server [8]. Sebuah dokumen XML umumnya terdiri dari bagian (node) berupa root node, element node, attribute node dan text node.

\subsection{PHP}

Hypertext Preprocessor atau PHP adalah bahasa pemrograman web yang digunakan untuk melakukan HTTP request. PHP mendukung pengiriman maupun pengolahan data dalam format XML. PHP pada umumnya dipadukan dengan engine database MySQL yang dapat digunakan untuk menyimpan data sesuai dengan kebutuhan dalam pengolahan web dengan database [9].

\subsection{DBMS}

Database Management System (DBMS) adalah sebuah aplikasi yang digunakan untuk memelihara serta mengelola basis data yang berbasis komputerisasi dalam ukuran besar yang terdiri dari penyimpanan, pengeditan, dan pengambilan data[10]. DBMS memiliki Bahasa basis data yang umumnya terdiri dari macam-macam intruksi yang dapat di proses oleh DBMS.

\section{Hasil dan Pembahasan}

Hasil dan Pembahasan memaparkan gambaran umum, tampilan aplikasi dan fungsional sistem. Pengujian dilakukan terhadap implementasi web service. Hasil pengujian dibahas pada bagian 4.1 sampai dengan bagian 4.3.

\subsection{Gambaran Umum Aplikasi}

Dashboard Executive Information System nasabah KUR (Kredit Usaha Rakyat) pada Bank $X$ adalah sistem informasi untuk mengelola dan memantau data nasabah KUR. Dashboard Executive Information System memungkinkan kepala cabang Bank X melihat data nasabah KUR secara visual, sehingga alur data nasabah KUR Mikro dapat dikontrol dengan lebih efektif. Data nasabah KUR Mikro diambil dari setiap unit dan diimplementasikan ke dalam grafik sehingga terlihat perbandingan pencapaian target jumlah nasabah antar kantor unit. Gambaran umum Dashboard Executive Information System ditunjukkan pada Gambar 2. 


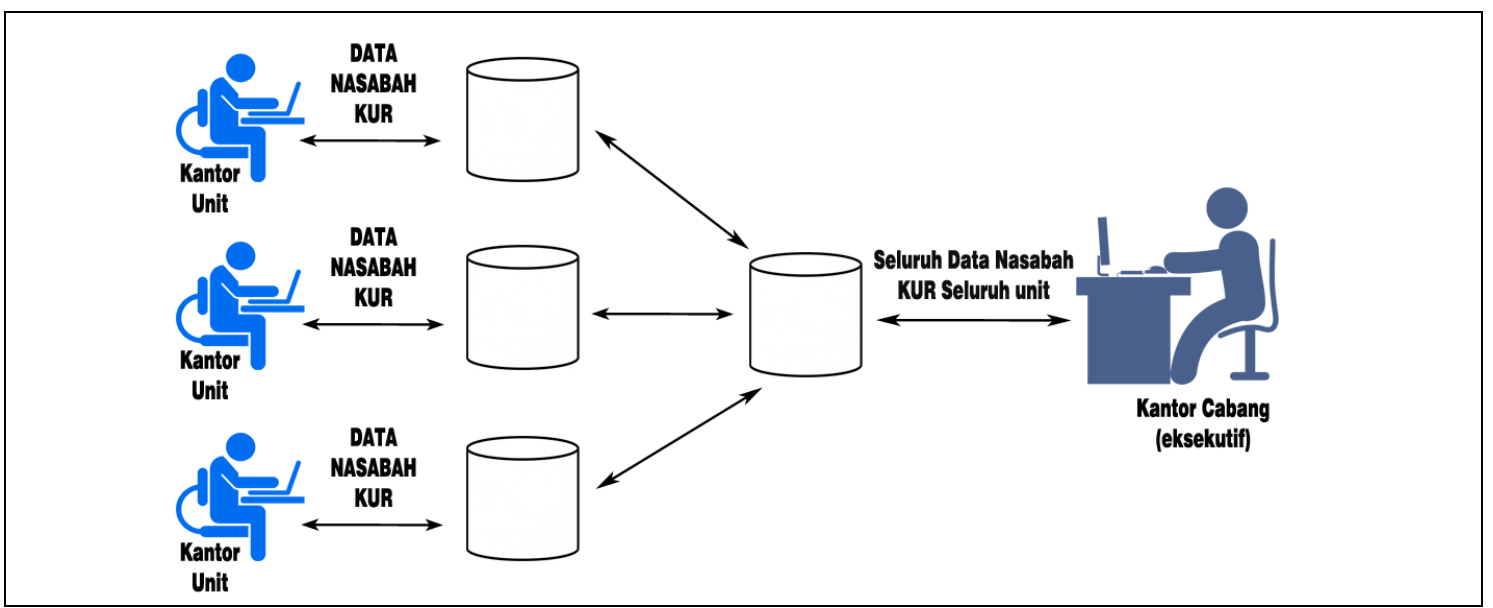

Gambar 2. Gambaran Umum Aplikasi

Dashboard Executive Information System menggunakan pendekatan terdistribusi dengan antarmuka web service sebagai jembatan komunikasi di dalam sistem. Komunikasi antara entitas dan sistem dapat digambarkan melalui diagram konteks. Diagram konteks sebagai penggambaran sistem secara keseluruhan [11] ditunjukkan pada Gambar 3.

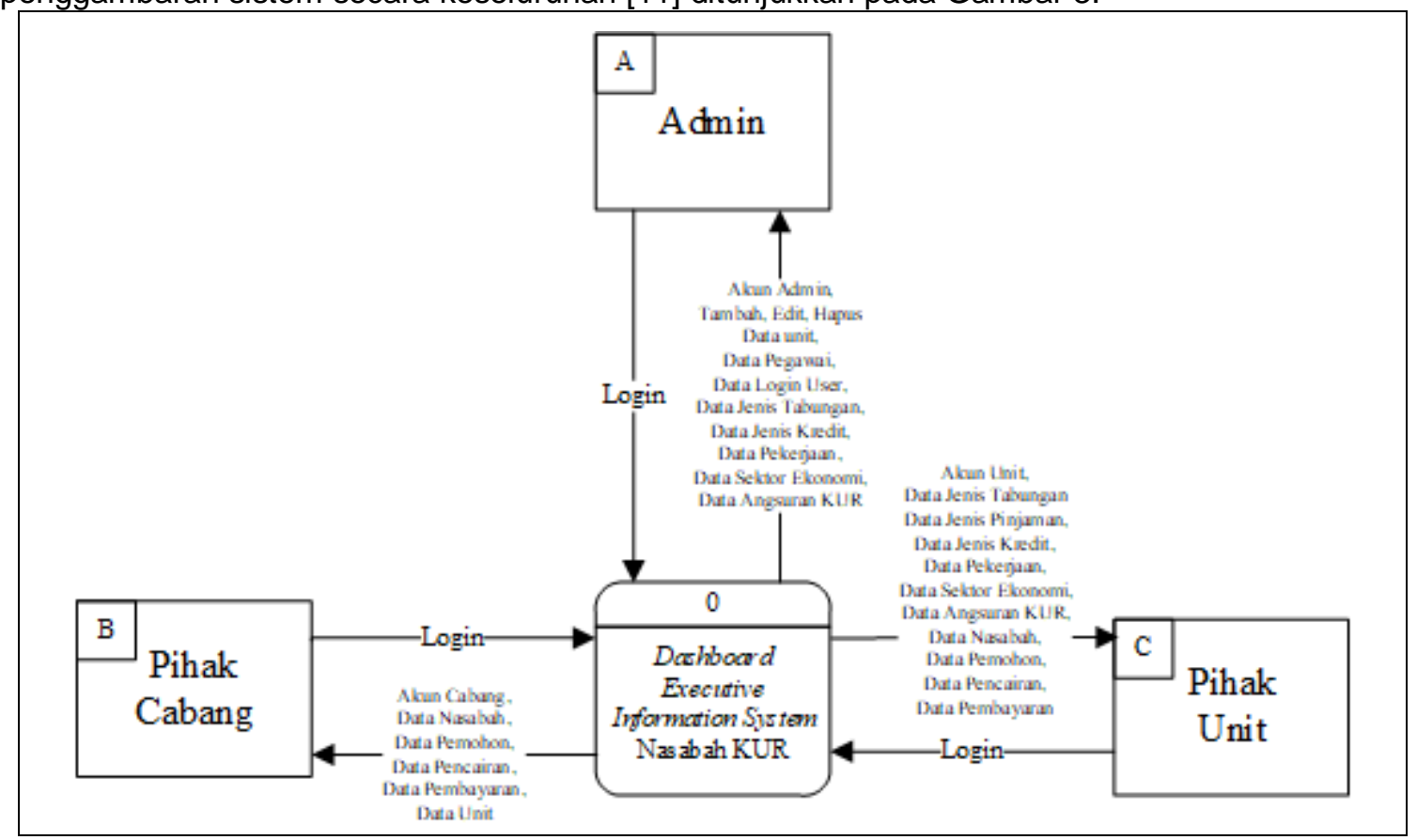

Gambar 3. Diagram Konteks Sistem

Diagram konteks pada Gambar 3 menunjukkan tiga entitas yang dapat berinteraksi langsung dengan sistem. Ketiga entitas yaitu entitas admin sebagai pihak manajemen data, entitas cabang sebagai pihak yang memantau target jumlah nasabah KUR dan entitas unit yang memasukkan data nasabah KUR ke dalam sistem. Data nasabah KUR ditampilkan dalam bentuk grafik sehingga lebih mudah untuk dipantau.

\subsection{Implementasi Web service}

Implementasi web service merupakan proses implementasian fitur-fitur dalam sistem yang telah dispesifikasikan menjadi web service. Proses implementasi meliputi web service untuk proses tambah data, web service proses edit data dan web service proses hapus data. Ketiga proses diaplikasikan untuk data nasabah, data pemohon, data pencairan dan data pembayaran. Gambar 4 menunjukkan web service salah satu proses yaitu tambah data nasabah. 


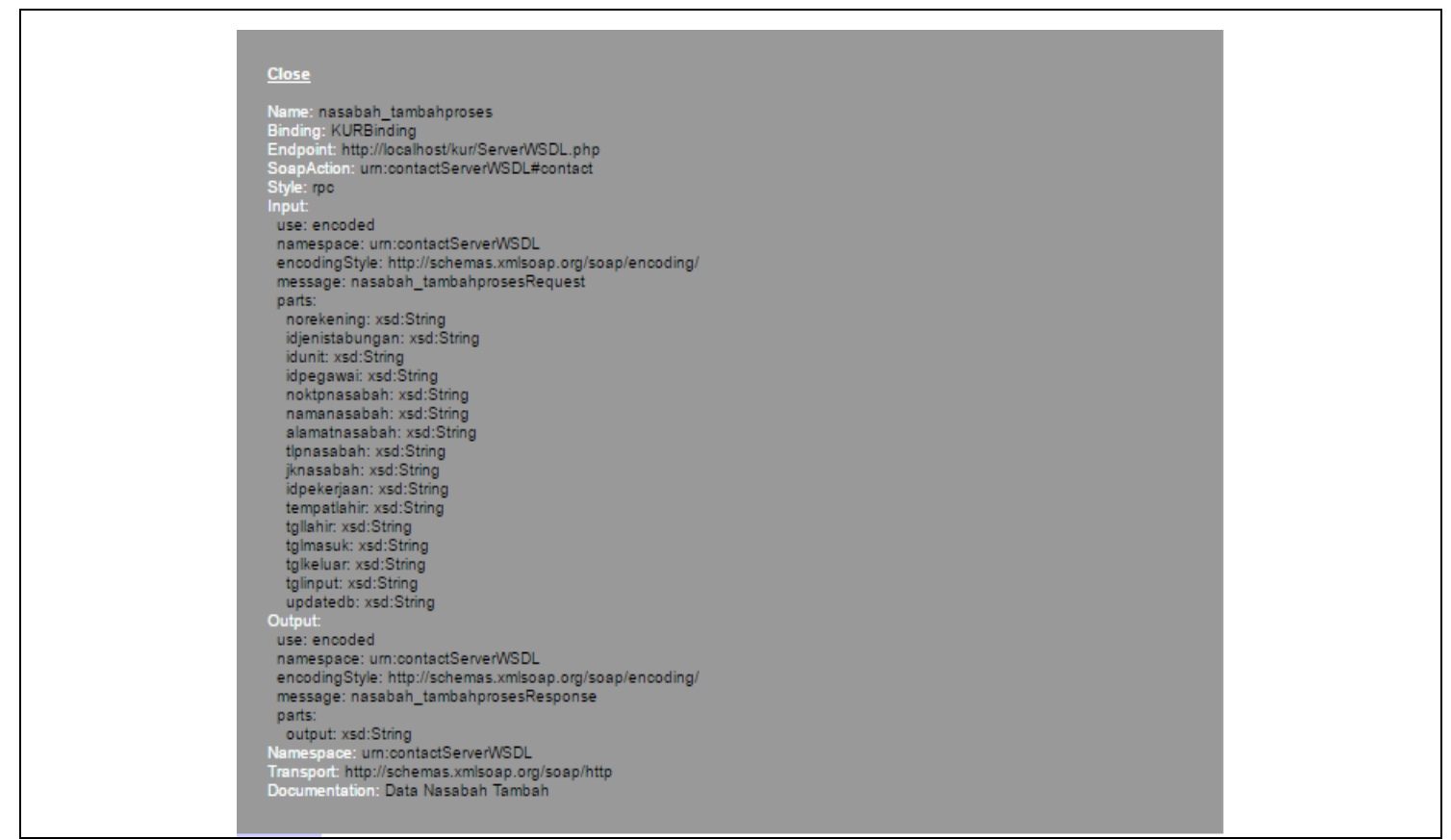

Gambar 4. Web service Tambah Data Nasabah

Web service untuk menambahkan data nasabah yang terdapat pada Gambar 4 diimplementasikan ke dalam kode program PHP. Kode program 1 menunjukkan potongan kode implementasi proses tambah data nasabah.

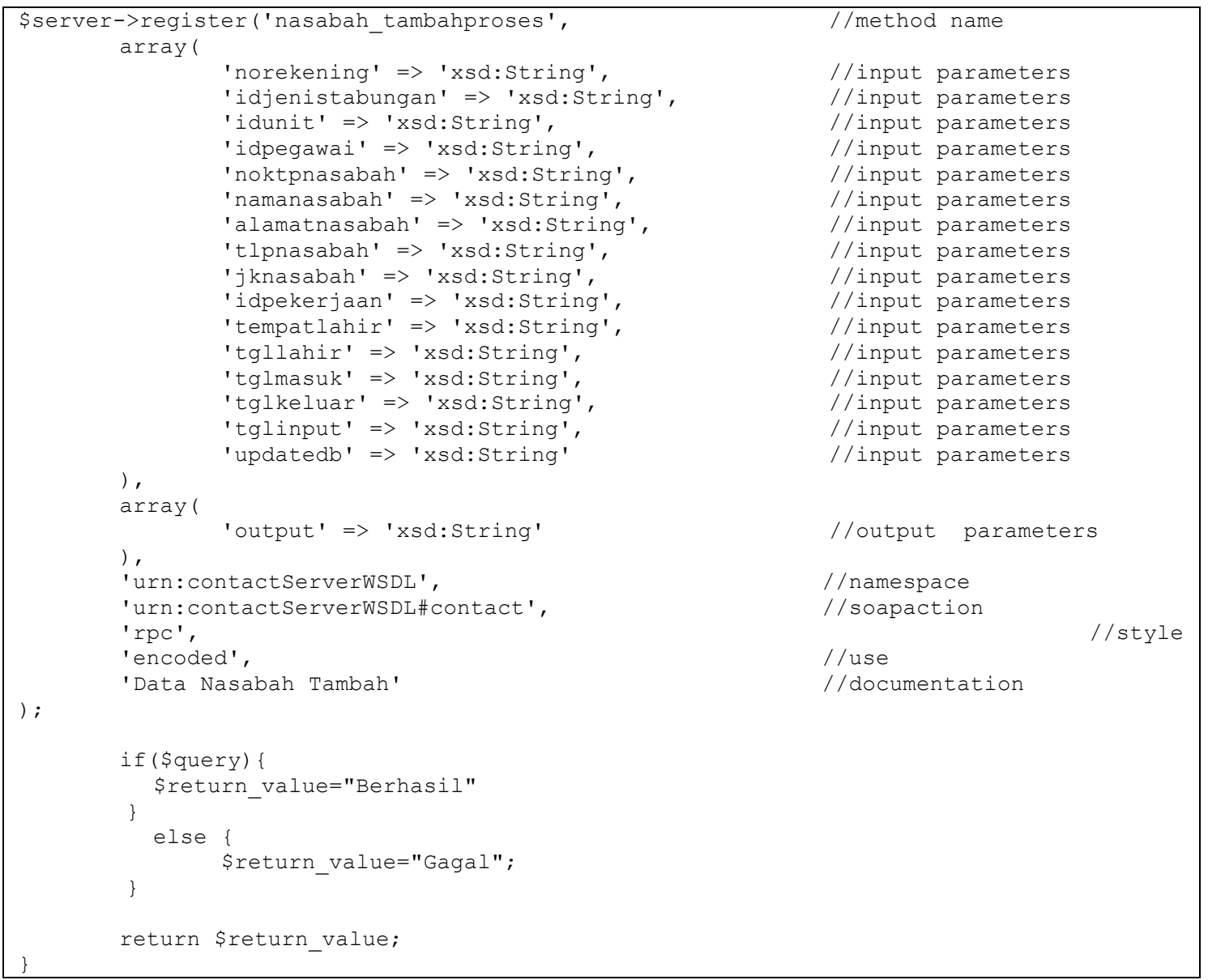


Kode Program 1. Implementasi Web service Tambah Nasabah

Web service untuk proses tambah, edit dan hapus data diimplementasikan ke dalam kode program dengan proses yang sama. Masing-masing data yaitu data nasabah, data pemohon, data pencairan dan data pembayaran memiliki proses tambah, edit dan hapus data.

\subsection{Antarmuka Sistem}

Seluruh pengguna yang masuk ke sistem harus melewati proses login. Gambar 5 menunjukkan halaman login yang tampilannya sama untuk seluruh penguna.

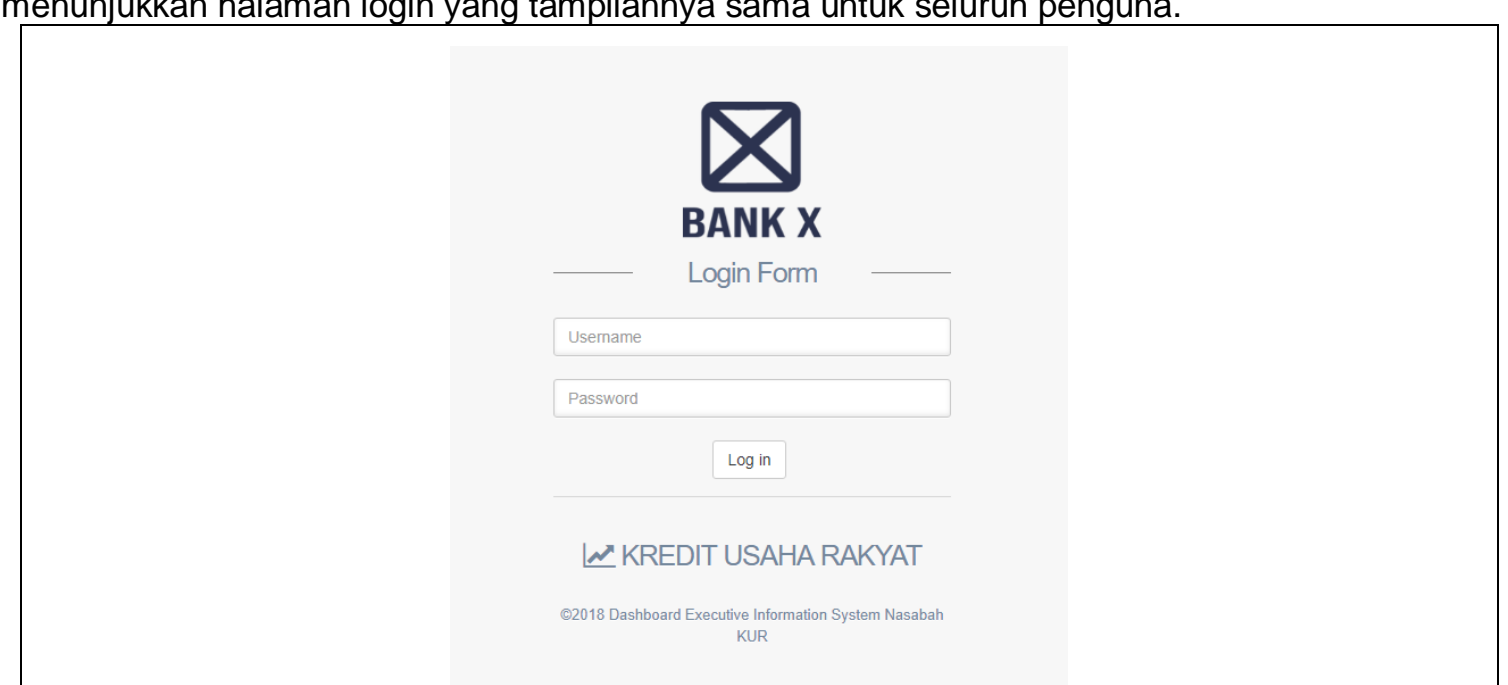

Gambar 5. Antarmuka Login Pengguna

Setiap entitas memiliki antarmuka berbeda yang disesuaikan dengan kebutuhannya setelah masuk ke sistem. Antarmuka untuk masing-masing entitas dijabarkan pada bagian 4.3.1 sampai dengan 4.3.3.

\subsubsection{Antarmuka untuk Administrator}

Administrator merupakan entitas yang bertugas untuk melakukan manajemen data pada fitur Unit, Pegawai, Login User, Jenis Tabungan, Jenis Kredit, Pekerjaan, Sektor Ekonomi, Sektor Ekonomi Deskripsi dan Angsuran KUR. Gambar 6 menunjukkan halaman dashboard untuk Administrator.

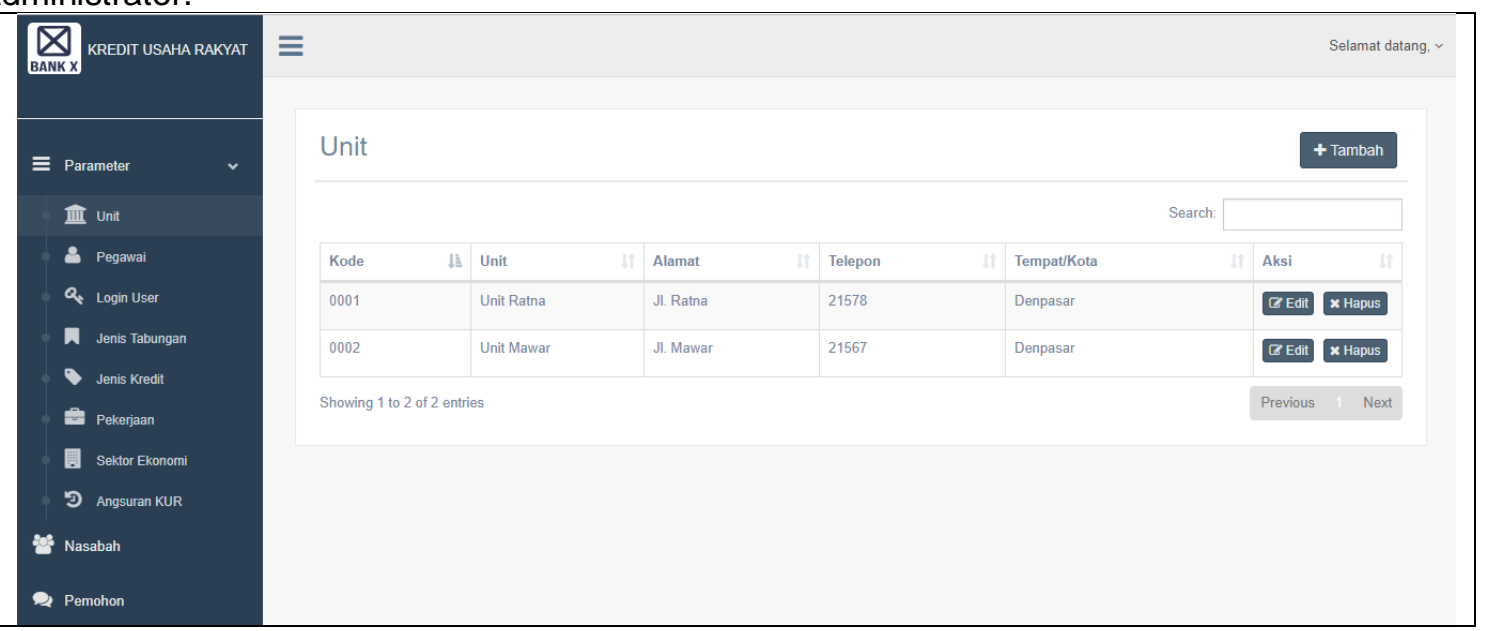

Gambar 6. Dashboard Administrator

Panel menu pada dashboard Administrator menunjukkan fitur-fitur yang dapat diakses oleh Administrator. Administrator dapat melakukan proses insert, update dan delete data dalam fitur Parameter (Unit, Pegawai, Login User, Jenis Tabungan, Jenis Kredit, Pekerjaan, Sektor Ekonomi dan Angsuran KUR). Administrator hanya memiliki akses untuk membaca (read) data 
di fitur Nasabah, Pemohon, Pencairan dan Pembayaran. Salah satu proses yang dapat dilakukan oleh Administrator adalah menambahkan data kantor unit seperti pada Gambar 7.

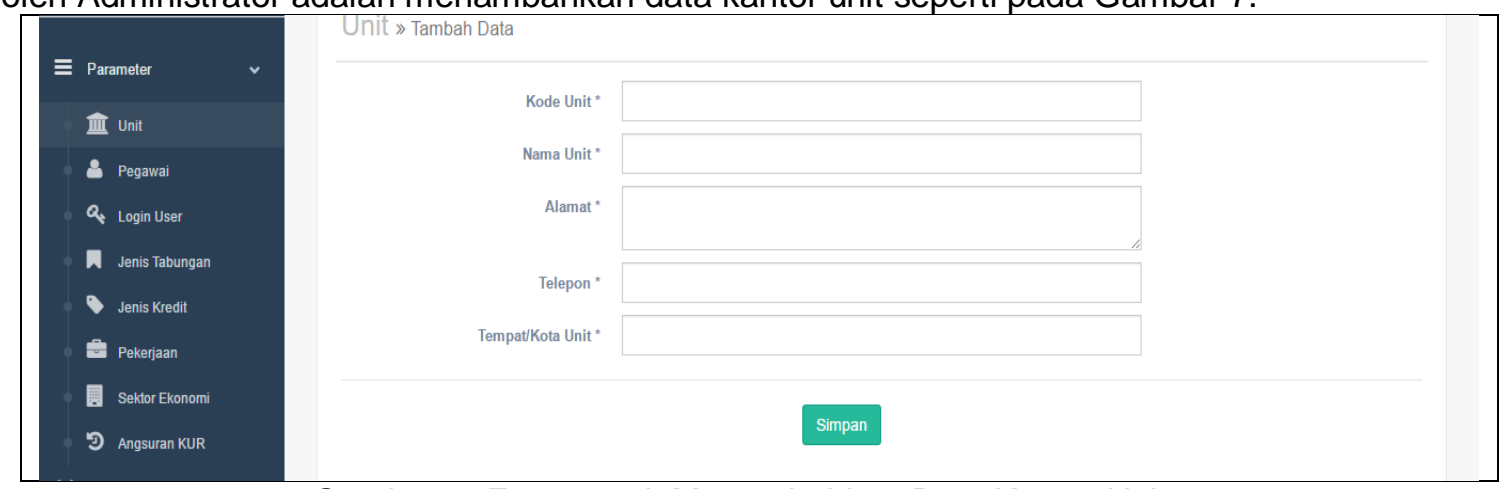

Gambar 7. Form untuk Menambahkan Data Kantor Unit

Gambar 7 menunjukkan tampilan proses penambahan (insert) data kantor unit pada halaman Administrator. Kolom-kolom yang tersedia pada form tambah data diisi oleh Administrator, kemudian data disimpan ke database dengan menekan tombol Simpan. Data kantor unit yang telah ditambahkan dapat diubah (edit) maupun dihapus (delete) hanya oleh Administrator.

\subsubsection{Antarmuka untuk Kantor Unit}

Unit adalah entitas yang bertugas untuk memanajemen data pada fitur Nasabah, Pemohon, Pencairan dan Pembayaran. Entitas Unit dapat mengakses sistem setelah didaftarkan dan diberikan data login oleh Administrator. Gambar 8 menunjukkan salah satu tampilan fitur Nasabah pada halaman Unit.

\begin{tabular}{|c|c|c|c|c|c|c|c|c|c|c|c|}
\hline$\bigotimes_{\text {BANK X }}$ KREDIT USAHA RAKYAT & \multicolumn{9}{|l|}{ Nasabah } & \multicolumn{2}{|c|}{ + Tambah } \\
\hline & & & & & & & Search: & & & & \\
\hline \multirow{2}{*}{ 央 Home } & No. Rekening لti & Unit & & No. KTP & Nama & & Alamat & At & ksi & & \\
\hline & 0001.01 .000001 .02 .6 & Unit Ratna & & 5105010407790002 & I Putu Ginastra & & Br Suana Dsn Cemlagilandan Desa Suana & & & & \\
\hline E Grafik & 0001.01 .000002 .02 .6 & Unit Ratna & & 5105015212750004 & Ni Nyoman Rahayu & & Banjar Sental Kangin Desa Ped & & & & \\
\hline \multirow{2}{*}{ E Parameter } & 0001.01 .000003 .02 .6 & Unit Ratna & & 5105017112660043 & Ni Ketut Sindri & & Banjar Sental Kawan Desaped & & & & \\
\hline & 0001.01 .000004 .02 .6 & Unit Ratna & & 5105017112640231 & Ni Wayan Masni & & Banjar Suana Desa Suana & & & & \\
\hline Nasabah & 0001.01 .000005 .02 .6 & Unit Ratna & & 51050119086660001 & I Wayan Sulastra & & Dusun Sental & & & & \\
\hline \multirow{2}{*}{ Pemohon } & 0001.01 .000006 .02 .6 & Unit Ratna & & 5105012507860005 & I Kadek Wijaya & & Banjar Sental Kangin Desa Ped & & & & \\
\hline & 0001.01 .000007 .02 .6 & Unit Ratna & & 5105013112600138 & I Wayan Tangkas & & Banjar Telaga Desa Kutampi Kaler & & & & \\
\hline (0] Pencairan KUR & 0001.01 .000008 .02 .6 & Unit Ratna & & 5105011307840002 & I Putu Panca Wardana & & Dusun Kutapang Kangin Desa Batununggul & & & & \\
\hline \multirow[t]{2}{*}{ 苗 Pembayaran } & 0001.01 .000009 .02 .6 & Unit Ratna & & 5105013112860017 & I Kadek Suartawan & & Banjar Sembir Desa Kutampi & & & & \\
\hline & 0001.01 .000010 .02 .6 & Unit Ratna & & 5105013112820126 & I Made Widiantara & & Dusun Limo Desa Kutampi Kaler & & & & \\
\hline 0 & \multicolumn{5}{|c|}{ Showing 1 to 10 of 63 entries } & & Previous & 4 & 5 & 67 & Next \\
\hline
\end{tabular}

Gambar 8. Tampilan Daftar Nasabah pada Halaman Unit

Entitas Unit diberikan hak akses untuk melakukan insert, update dan delete data nasabah, pemohon, pencairan KUR, pembayaran. Entitas Unit hanya dapat melihat (read) data pada fitur Parameter (Unit, Pegawai, Login User, Jenis Tabungan, Jenis Kredit, Pekerjaan, Sektor Ekonomi dan Angsuran KUR). Salah satu proses manajemen data nasabah yang dapat dilakukan oleh entitas Unit terlihat pada Gambar 9. 


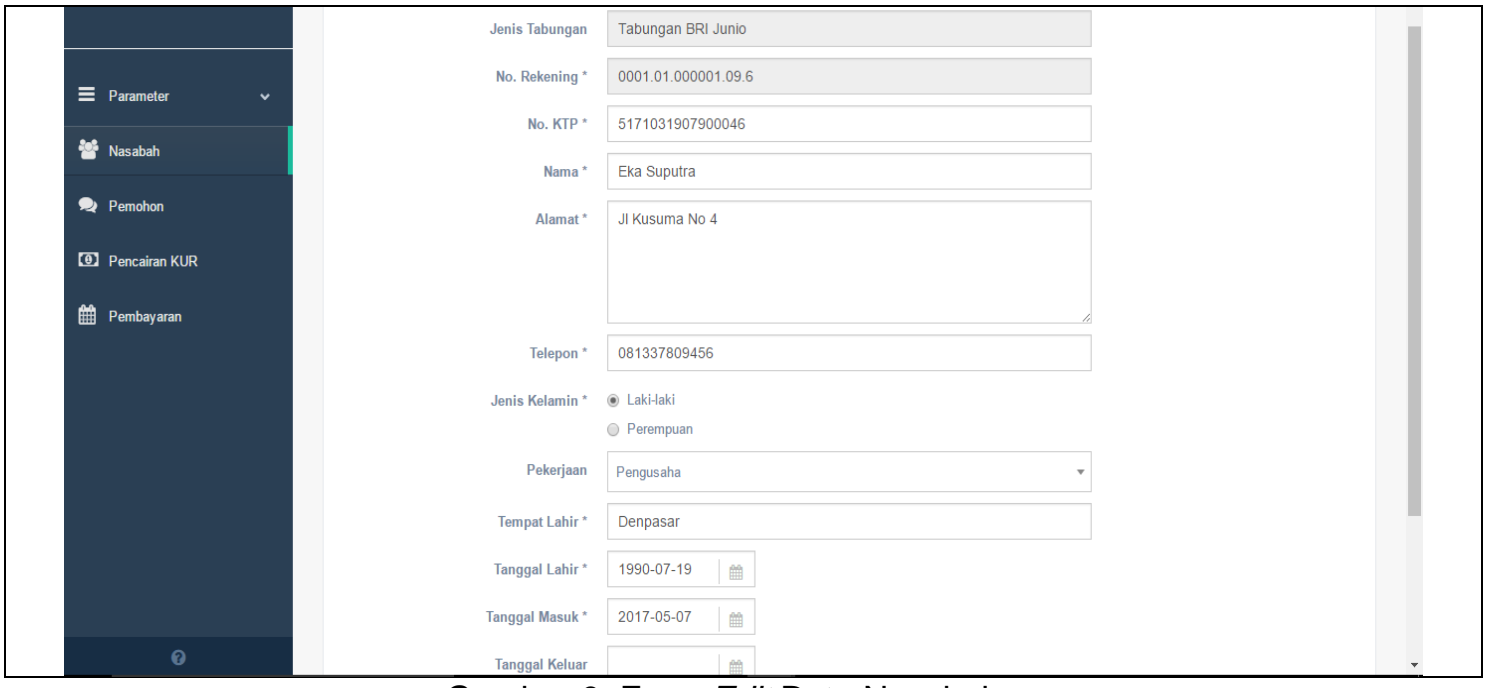

Gambar 9. Form Edit Data Nasabah

Entitas Unit dapat melakukan penyuntingan data nasabah mulai dari data No KTP sampai selesai. Data yang telah selesai diperbarui dapat langsung disimpan ke dalam database dengan menekan tombol Simpan.

\subsubsection{Antarmuka untuk Kantor Cabang}

Cabang (kantor cabang) adalah entitas yang bertugas untuk memantau data nasabah KUR Mikro. Pemantauan dapat dilakukan melalui fitur Grafik pada sistem. Salah satu grafik yang disediakan untuk entitas cabang adalah komparasi total nasabah pemohon dan penerima KUR. Perbandingan total nasabah pemohon KUR di setiap kantor unit ditunjukkan pada Gambar 10.

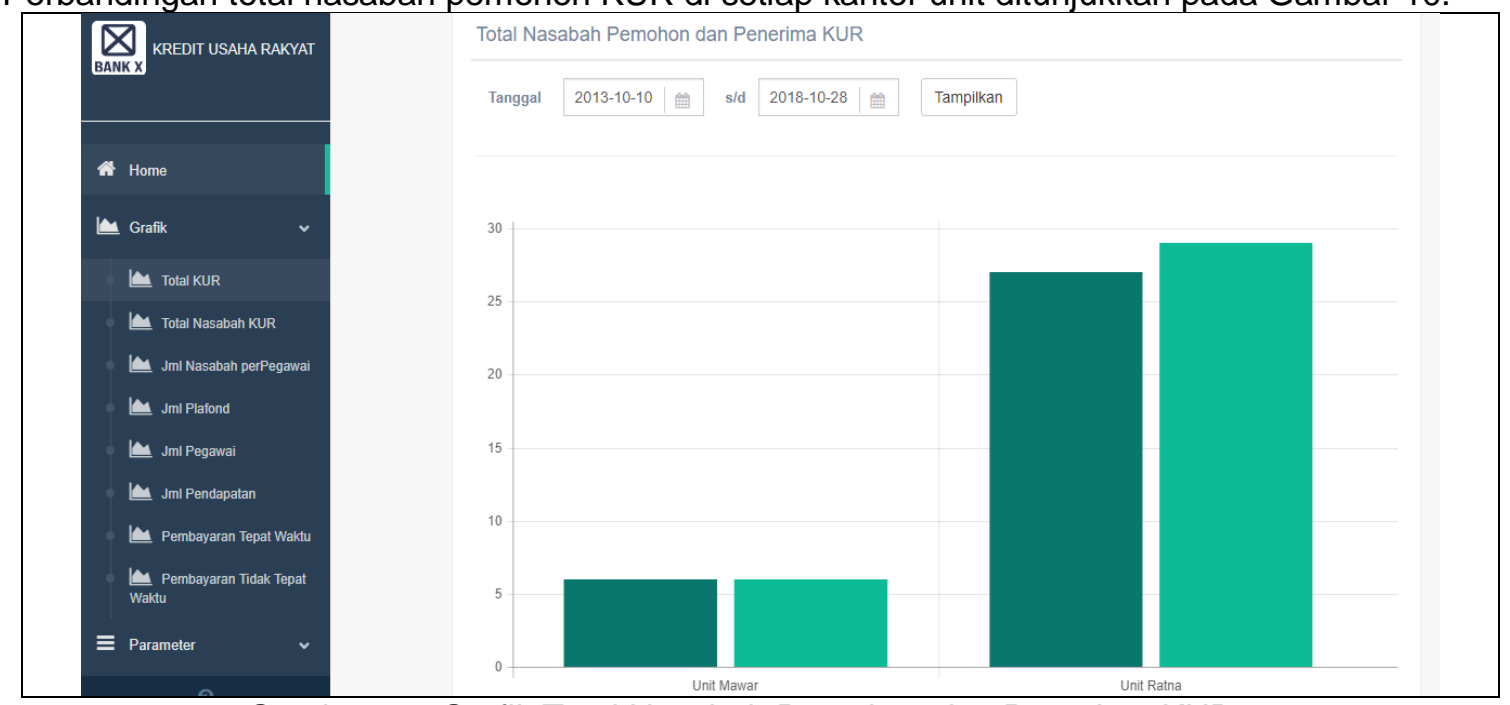

Gambar 10. Grafik Total Nasabah Pemohon dan Penerima KUR

Perbandingan total nasabah pada Gambar 10 didapatkan berdasarkan data yang telah dimasukkan oleh setiap unit melalui sistem. Cabang dapat mengatur preferensi rentang waktu pada bagian atas grafik. Entitas cabang dapat melihat grafik data total penyaluran KUR, total nasabah KUR, jumlah nasabah per pegawai, jumlah plafond kredit yang tersedia, jumlah pegawai, jumlah pendapatan, jumlah pembayaran tepat waktu dan pembayaran tidak tepat waktu. Data nasabah tersebut dapat diakses melalui fitur Grafik pada panel fitur sistem.

\subsection{Pengujian Sistem}

Pengujian fungsionalitas sistem dilakukan sebagai verifikasi bahwa sistem yang dibangun memenuhi spesifikasi kebutuhan dan berjalan sesuai skenario yang didefinisikan. 
Pengujian dilakukan dengan melihat kesesuaian antara masukan dan keluaran setiap fungsi tanpa memperhatikan jalannya eksekusi program.

Proses pengujian mengharuskan adanya minimal dua perangkat untuk simulasi kantor cabang dan kantor unit. Uji coba dijalankan secara lokal menggunakan satu komputer yang sudah dipasangi dengan aplikasi Oracle VM Virtual Box. Virtualisasi dilakukan pada komputer sehingga terdapat dua komputer virtual dengan sistem operasi Windows 7 dan satu komputer fisik dengan Windows 10. Mesin virtual menjadi entitas unit dan komputer utama berfungsi sebagai cabang, sehingga seolah-olah terdapat dua unit dan satu cabang

Pengujian dilakukan pada fitur-fitur dan halaman untuk kantor unit dan kantor cabang. Pengujian untuk kantor unit dilakukan pada web service data nasabah, data pemohon, data pencairan dan data pembayaran. Pengujian pada kantor cabang meliputi halaman-halaman grafik serta fungsi sinkronisasi yang terdapat pada Dashboard Executive Information System untuk memantau data nasabah KUR. Tabel 1 menunjukkan hasil pengujian yang telah dilakukan.

Tabel 1. Hasil Pengujian Sistem Unit dan Sistem Cabang

\begin{tabular}{|c|l|c|}
\hline \multicolumn{1}{|c|}{ No Pengujian } & Status Uji \\
\hline A. Pengujian Sistem Unit & Sukses \\
\hline 1 & Halaman Login & Sukses \\
\hline 2 & Halaman Home & Sukses \\
\hline 3 & Halaman Grafik & Sukses \\
\hline 4 & Halaman Nasabah & Sukses \\
\hline 5 & Halaman Pemohon & Sukses \\
\hline 6 & Halaman Pencairan KUR & Sukses \\
\hline 7 & Halaman Pembayaran & Sukses \\
\hline B. Pengujian Sistem Cabang & Sukses \\
\hline 1 & Halaman Login & Sukses \\
\hline 2 & Halaman Home & Sukses \\
\hline 3 & Halaman Grafik Total KUR & Sukses \\
\hline 4 & Halaman Grafik Total Nasabah KUR & Sukses \\
\hline 5 & Halaman Grafik Jumlah Nasabah Perpegawai & Sukses \\
\hline 6 & Halaman Grafik Jumlah Plafond & Sukses \\
\hline 7 & Halaman Grafik Jumlah Pegawai & Sukses \\
\hline 8 & Halaman Grafik Jumlah Pendapatan & Sukses \\
\hline 9 & Halaman Grafik Pembayaran Tepat Waktu & \\
\hline 10 & Halaman Grafik Pembayaran Tidak Tepat Waktu & \\
\hline
\end{tabular}

Hasil pengujian memperlihatkan seluruh halaman yang dujicobakan memiliki status sukses. Status uji sukses menunjukkan sistem telah memenuhi spesifikasi kebutuhan dan berjalan sesuai skenario yang didefinisikan.

Hasil analisa sistem menghasilkan beberapa kelebihan dan kekurangan yang terlihat. Kelebihan-kelebihan sistem yang dibangun antara lain: (1) adanya fasilitas untuk sinkronisasi data nasabah KUR antar kantor unit; (2) informasi perkembangan dan perbandingan jumlah nasabah disajikan dalam bentuk grafik, (3) penerapan teknologi web service mendukung pertukaran data secara real-time, serta (4) terdapat dukungan sinkronisasi dua arah antar kantor unit yaitu insert, update, delete dan read dari database.

Kelebihan yang dimiliki oleh sistem masih diikuti dengan beberapa kelemahan yang terlihat. Kelemahan yang terlihat diantaranya: (1) sistem belum dapat melakukan sinkronisasi pada struktur tabel database yang berbeda; (2) sinkronisasi real-time harus dilakukan oleh Administrator dengan menekan tombol untuk menarik data, serta (3) sistem belum mampu untuk mengintegrasikan sistem dengan database selain MySQL.

\section{Kesimpulan}

Penelitian ini menghasilkan Dashboard Executive Information System yang memudahkan kantor cabang memantau target penyaluran KUR Mikro di setiap kantor unit dalam Bank X. Dashboard Executive Information System dikembangkan dengan pendekatan terdisribusi yang sesuai dengan kondisi antara kantor unit dan kantor cabang. Komunikasi dalam sistem terdistribusi dijembatani dengan web service. Entitas yang dapat berinteraksi langsung dengan Dashboard Executive Information System adalah admin, unit (kantor unit) dan cabang (kantor cabang). Sistem terdiri dari 17 antarmuka. Hasil pengujian menunjukkan bahwa 17 
halaman web dapat ditampilkan dengan status uji sukses. Hasil analisa menunjukkan beberapa kelebihan yang dimiliki sistem yaitu dukungan sinkronisasi data nasabah antar kantor unit, adanya grafik untuk menyajikan perbandingan jumlah nasabah, penerapan teknologi web service yang mendukung pertukaran data secara real-time, serta sinkronisasi dua arah antar kantor unit yaitu insert, update, delete dan read dari database.

\section{Daftar Pustaka}

[1] A. P. Windarto, "Implementasi JST dalam Menentukan Kelayakan Nasabah Pinjaman KUR pada Bank Mandiri Mikro Serbelawan dengan Metode Backpropogation," J. Sains Komputer\&Informatika, vol. 1, no. 1, pp. 12-23, 2017.

[2] P. S. R. Dhore, I. Gangwar, P. Mishra, R. Sharma, and R. Singh, "Systematic Approach for Composing Web Service using XML,"IEEE, 2012, no. July.

[3] J. Park, H. Hwang, J. Yun, and I. Moon, "Study of HTML5 WebSocket for a Multimedia Communication," Int. J. Multimed. Ubiquitous Eng., vol. 9, no. 7, pp. 61-72, 2014.

[4] D. Qiu, J. Liu, and G. Zhao, "Design and Application of Data Integration Platform Based on Web Services and XML," in International Conference on Electronics Information and Emergency Communication (ICEIEC), 2016, pp. 253-256.

[5] H. Deviana, "Penerapan XML Web service pada Sistem Distribusi Barang," J. Generic, vol. 6, no. 2, pp. 61-70, 2011.

[6] E. Kurniawan, "Implementasi Rest Web Service untuk Sales Order dan Sales Tracking Berbasis Mobile," Jurnal. EKSIS, vol. 7, no. 1, pp. 1-12, 2014.

[7] D. S. Wicaksono and F. N. Hakim, "Media Pembelajaran Fisika Interaktiv Bahasan Kapasitor Berbasis Flash dan Xml," Sentra Penelitian. Engineering. dan Edukasi, vol. 3, no. 2, pp. 47-54, 2011.

[8] P. W. Buana, I. M. Sukarsa, I. Bagus, G. Purwania, and I. Gusti, "Real Time Trans Bus Tracking and Passenger Information System using Hybrid Application Technology," International. Journal. Software. Engineering. Its Applications., vol. 10, no. 9, pp. 35-50, 2016.

[9] I. N. S. Paliwahet, I. M. Sukarsa, and I. K. G. D. Putra, "Pencarian Informasi Wisata Daerah Bali menggunakan Teknologi Chatbot," Lontar Komputer., vol. 8, no. 3, pp. 144 153, 2017.

[10] N. W. B. P. W. Sukarsa, I Made; Wisswani, "Data Exchange Between Information System," JATIT, vol. 60, no. 2, pp. 417-422, 2014.

[11] M. Sukarsa and G. Made Rupayana, "Rancang Bangun Web Iklan Berbasis Mobile," Lontar Komputer., vol. 2, no. 1, pp. 91-109, 2011. 